\title{
SIKAP MAHASISWA UNIVERSITAS PGRI PALANGKA RAYA TERHADAP PELESTARIAN LINGKUNGAN
}

\author{
DEDY NORSANDI \\ Dosen Program Studi Pendidikan Geografi, Fakultas Keguruan dan IImu Pendidikan \\ Universitas PGRI Palangka Raya \\ e-mail : dedy_norsandi@yahoo.com
}

\begin{abstract}
The objective of the research is to study the relationship between knowledge about ecosystem, perception about environmental health and motivation toward the environmental preservation and students attitudes toward the environmental conservation. The total number of sample were 120 students chosen by multistage random sampling at the University PGRI Palangka Raya.

The research indicates that there are positive correlation between: (1) knowledge about ecosystem and students' attitudes toward the environmental conservation, (2) perception about environmental health and students' attitudes toward the environmental conservation and (3) motivation toward environmental preservation and students' attitudes toward the environmental conservation.

Therefore, the higher the levels of knowledge about ecosystem, perception about environmental health and motivation toward environmental preservation, the more positive students' attitudes toward the environmental conservation will be.
\end{abstract}

Keywords : attitude, environmental conservation

\section{ABSTRAK}

Objek dari penelitian ini adalah untuk mempelajari hubungan antara pengetahuan tentang ekosistem, persepsi tentang kesehatan lingkungan dan motivasi terhadap pelestarian lingkungan dan sikap mahasiswa terhadap pelestarian lingkungan. Jumlah sampel sebanyak 120 mahasiswa yang dipilih secara acak bertingkat di Universitas PGRI Palangka Raya.

Hasil penelitian menujukkan bahwa terdapat hubungan yang positif antara: (1) pengetahuan tentang ekosistem dan sikap mahasiswa terhadap pelestarian lingkungan, (2) persepsi tentang kesehatan lingkungan dan sikap mahasiswa terhadap pelestarian lingkungan dan (3) motivasi terhadap pelestarian lingkungan dan sikap mahasiswa terhadap pelestarian lingkungan.

Oleh karena itu lebih tinggi tingkat pengetahuan terhadap ekosistem, persepsi terhadap kesehatan lingkungan dan motivasi untuk pelestarian lingkungan, sikap mahasiswa akan berpengaruh lebih pasti untuk pelestarian lingkungan.

Kata kunci: sikap, pelestarian lingkungan

\section{PENDAHULUAN}

Sumber daya alam merupakan salah satu modal dasar pembangunan nasional yang harus dimanfaatkan sebesar-besarnya bagi kemakmuran dan kesejahteraan masyarakat. Akan tetapi oleh karena kemampuan pulinnya memakan waktu lama atau tidak pulih sama sekali maka pemanfaatan tersebut harus dilakukan secara arif dan bijaksana, tidak sampai merusak supaya tetap berfungsi sebagai sumber yang mendukung pembangunan secara berkelanjutan. Pemanfaatan sumber daya alam seperti hutan, bahan tambang dan lainnya harus dilakukan dengan teknologi tepat guna dan berhasil guna 
supaya tidak mengganggu kelestariannya. Dengan demikian modal dasar tersebut makin besar manfaatnya bagi kesejahteraan masyarakat yang dapat dinikmati bukan saja pada saat sekarang tetapi juga pada masa-masa yang akan datang.

Dipandang dari segi ekologi, sumber daya alam tersebut adalah bagian yang tak terpisahkan dari suatu ekosistem sebagai satu kesatuan interaksi timbal balik antara makhluk hidup (biotik) dengan makhluk tak hidup (abiotik) dan antar makhluk hidup itu sendiri (Soemarwoto, 2004). Manusia adalah salah satu unsur dalam suatu ekosistem yang memiliki kemampuan memanfaatkan unsur-unsur lain untuk kepentingannya. Oleh karena itu seharusnya manusia juga bertindak sebagai pengelola yang baik, aktif dan produktif menjaga kelestariannya.

Sejalan dengan pertumbuhan penduduk dan target pertumbuhan ekonomi yang cenderung meningkat maka tekanan terhadap sumber daya alam semakin meningkat. Ini ditandai dengan peningkatan pengrusakan lingkungan seperti penebangan hutan secara sembarangan, pengkonversian areal hutan mangrove menjadi lahan tambak udang dan pengambilan terumbu karang untuk bahan bangunan. Di samping itu banyak terjadi pengrusakan hutan akibat perladangan berpindah bahkan akhir-akhir ini untuk menghemat biaya pembukaan lahan perkebunan kelapa sawit terjadi pembakaran lahan yang melenyapkan ratusan ribu sampai jutaan hektar hutan. Pengrusakan-pengrusakan itu terjadi karena manusia berlomba memenuhi tujuan-tujuan jangka pendeknya, lupa memperkirakan akibat-akibatnya bagi masa depan pembangunan berkelanjutan.
Kerusakan hutan dan lahan-lahan serapan mengakibatkan banjir, hilangnya: gudang plasma nutfah, simpanan karbohidrat dalam bentuk kayu, siklus hidrologi, siklus karbon oksigen, ekosistem biota, sumber informasi untuk penelitian ilmiah dan sebagainya. Demikian juga kerusakan ekosistem mangrove mengakibatkan hilangnya: peran yang menunjang sumberdaya perikanan di pantai, tempat persinggahan burung-burung, persediaan kayu untuk bangunan dan lain-lain. Rusaknya ekosistem terumbu karang mengakibatkan hilangnya pelindung fisik terhadap pantai dan hilangnya habitat untuk berkembangnya produk ikan karang, udang karang, alga, teripang, kerang dan lainnya.

Perilaku pengrusakan lingkungan tersebut di atas mencerminkan sikap masyarakat dalam menanggapi situasi yang dihadapinya. Mereka berlomba memenuhi kebutuhannya tanpa mempedulikan akibat-akibat yang timbul, baik terhadap kerusakan lingkungan maupun terhadap pelanggaran aturan-aturan pengelolaan lingkungan. Untuk menyelamatkan lingkungan hidup dari kerusakan maka seharusnya sikap negatif masyarakat seperti itu dirubah menjadi sikap positif yang mencintai pelestarian lingkungan. Yang menjadi pertanyaan adalah faktor-faktor apa yang dapat mempengaruhi perubahan sikap tersebut dan siapa yang diajukan menjadi responden penelitian. Pada penelitian ini diajukan sebagai faktor-faktor yang dapat mempengaruhi sikap terhadap pelestarian lingkungan adalah pengetahuan tentang ekosistem, persepsi terhadap kesehatan lingkungan dan motivasi mengenai pemeliharaan lingkungan. Responden adalah mahasiswa sebagai bagian dari masyarakat ilmiah yang 
memiliki kelebihan-kelebihan dalam hal pengetahuan tentang lingkungan hidup. Sebagai anggota masyarakat mereka berkewajiban memelihara kelestarian lingkungan hidup serta mencegah pencemaran dan perusakan lingkungan hidup (UU. NO. 23, Tahun 1997).

\section{Perumusan Masalah}

Berdasarkan uraian di atas maka permasalahan penelitian ini adalah 1) apakah terdapat hubungan antara pengetahuan tentang ekosistem dengan sikap terhadap pelestarian lingkungan?, 2) apakah terdapat hubungan antara persepsi terhadap kesehatan lingkungan dengan sikap terhadap pelestarian lingkungan?, dan 3). apakah terdapat hubungan antara motivasi mengenai pemeliharaan lingkungan dengan sikap terhadap pelestarian lingkungan?

\section{KERANGKA BERPIKIR}

\section{Hubungan antara Pengetahuan tentang Ekosistem dengan Sikap terhadap Pelestarian Lingkungan}

Salah satu unsur pengaruh sikap terhadap pelestarian lingkungan adalah pengetahuan tentang ekosistem. Sikap adalah kecenderungan berbuat terhadap sesuatu obyek secara positif ataupun negatif. Lingkungan yang menjadi obyek pelestarian adalah faktor-faktor biotik dan abiotik. Semua faktor-faktor mempunyai fungsi yang satu sama lain saling berinteraksi membentuk ekosistem dan bersama-sama melestarikan kehidupan di bumi. Manusia bagian dari ekosistem yang sangat berkepentingan dengan kelestarian faktor-faktor biota dan nonbiota tersebut. Interaksi antara manusia dengan faktorfaktor tersebut memberi nilai yang lebih tinggi bagi manusia dari pada bagi faktor-faktor biota dan nonbiota. Sebagai contoh tumbuhan hijau yang dapat berfotosintesis menghasilkan karbohidrat yang merupakan faktor pengaruh kehidupan manusia, tanpa keberadaannya manusia tidak dapat hidup dan sebaliknya tanpa keberadaan manusia, tumbuhan hijau tersebut tetap ada.

Hubungan ketergantungan kehidupan manusia dengan faktor-faktor biotik dan abiotik kurang disadari sehingga manusia menganggap dirinya lebih tinggi dan terpisah dari keberadaan faktor-faktor itu. Hal ini merupakan awal yang berkembang menjadi sikap negatif manusia terhadap lingkungan. Oleh karena itu untuk merubah sikap negatif menjadi sikap positif yang mencintai lingkungan diperlukan adanya pengetahuan tentang ekosistem. Pengetahuan tentang ekosistem dapat diperoleh dari proses pembelajaran atau dari pengalaman. Pengetahuan adalah segala sesuatu yang diketahui tentang obyek tertentu termasuk di dalamnya ilmu meliputi pengetahuan spesifik, pengetahuan cara atau metode dan pengetahuan universal. Ekosistem adalah kesatuan antara organisme dengan lingkungannya yang mengarah kepada terbentuknya struktur makanan. Jadi, pengetahuan tentang ekosistem adalah pengetahuan yang meliputi pengetahuan spesifik mengenai unsur biotik dan abiotik, pengetahuan tentang cara mengenai pelestarian lingkungan dan pengetahuan universal mengenai teori ekosistem yang meliputi hubungan atau fungsi dari masing-masing komponen atau unsur dalam ekosistem.

Dengan adanya pengetahuan di bidang ekosistem, sikap negatif yang merusak lingkungan dapat diminimalkan atau bahkan dapat dieliminasi. Orang yang mempunyai pengetahuan 
ekosistem dengan baik bersikap positif terhadap lingkungan, tidak merusak dan mencegah tindakan yang merugikan kelestarian lingkungan yang dibuktikan melalui perbuatannya sehari-hari. Atas dasar itulah maka diduga terdapat hubungan positif antara pengetahuan tentang ekosistem dengan sikap terhadap pelestarian lingkungan. Dengan kata lain makin tinggi pengetahuan seseorang tentang ekosistem maka semakin meningkat sikap positifnya terhadap pelestarian lingkungan.

\section{Hubungan antara Persepsi terhadap Kesehatan Lingkungan dengan Sikap terhadap Pelestarian Lingkungan}

Kesehatan lingkungan adalah keadaan lingkungan yang higienis, bebas dari semua faktor yang menimbulkan akibat yang merugikan pada perkembangan fisik, kesehatan dan kelangsungan hidup. Kesehatan lingkungan yang dimaksud lebih diarahkan kepada penyediaan air bersih, udara bersih dan lingkungan bersih dalam arti bebas dari sampah dan bahan pencemar.

Persepsi adalah cara menanggapi atau menafsirkan segala informasi yang diterima oleh indera dan mengorganisasikan informasi yang ada di lingkungan sekitar. Tiap individu mempunyai persepsi yang berbeda terhadap situasi yang sarna. Hal ini disebabkan oleh perbedaan ketertarikan berdasarkan pengalaman, perhatian dan harapan seseorang pada aspek tertentu. Tidak mungkin bagi seseorang menanggapi dan menilai sekaligus semua informasi yang tersedia di lingkungan dan ini menyebabkan penerimaannya harus selektif. Faktor-faktor yang mempengaruhi seleksi adalah faktor perangsang yang menarik, dan faktor individu seperti keadaan psikologis, sikap yang terbentuk dengan baik dan karakteristik seseorang. Persepsi terhadap kesehatan lingkungan berarti cara individu menanggapi dan mengorganisasikan informasi tentang kesehatan lingkungan supaya memberi makna bagi lingkungan mereka.

Seseorang yang mempersepsikan kesehatan lingkungan agar bermakna di lingkungannya mempunyai sikap positif terhadap pelestarian lingkungan. Ini berarti bahwa kesadaran seseorang tentang kesehatan lingkungan berpengaruh dalam sikapnya terhadap pelestarian lingkungan. Kesadaran terhadap kesehatan lingkungan adalah persepsi terhadap kesehatan lingkungan. Oleh karena itu diduga terdapat hubungan positif antara persepsi mahasiswa terhadap kesehatan lingkungan dengan sikap mahasiswa terhadap pelestarian lingkungan. Dengan kata lain makin baik persepsi seseorang terhadap kesehatan lingkungan maka semakin meningkat sikap positifnya terhadap pelestarian lingkungan.

\section{Hubungan antara Motivasi mengenai Pemeliharaan Lingkungan dengan Sikap terhadap Pelestarian Lingkungan}

Motivasi adalah dorongan ke arah tindakan terhadap sesuatu obyek. Motivasi mengenai pemeliharaan lingkungan berarti dorongan yang datang baik dari dalam diri sendiri (intrinsik) ataupun dari luar (ekstrinsik) untuk mempertahankan dan menjaga kondisi lingkungan. Motivasi yang datang dari dalam diri sendiri meliputi niat sendiri untuk berupaya melakukan pemeliharaan lingkungan dan yang datang dari luar adalah ketaatan dan kesediaan seseorang menuruti aturan pemeliharaan lingkungan. 
Lingkungan yang menjadi obyek pemeliharaan adalah hutan, lahan pertanian dan keberadaan satwa liar yang tidak asing bagi mahasiwa karena semua obyek itu berada di sekitar apalagi bagi mahasiswa responden yang umumnya berasal dari daerah. Motivasi yang timbul karena rangsangan dari luar menunjukkan bahwa motivasi dapat dipengaruhi. Adanya motivasi seseorang terhadap obyek tertentu dapat dilihat dari tindakan-tindakannya. Tindakan memelihara adalah usaha menjaga dan merawat benda-benda yang ada dalam konteks lingkungan benda-benda tersebut meliputi faktor biotik dan faktor abiotik. Bila seseorang mempunyai motivasi untuk memelihara dan menjaga kondisi lingkungan, berarti ia bersikap positif terhadap pelestarian lingkungan.

Atas dasar uraian dapat diduga terdapat hubungan positif antara motivasi mengenai pemeliharaan lingkungan dengan sikap terhadap pelestarian lingkungan. Dengan kata lain makin kuat motivasi seseorang mengenai pemeliharaan lingkungan maka semakin positif sikapnya terhadap pelestarian lingkungan.

\section{METODOLOGI PENELITIAN}

Tujuan penelitian ini adalah untuk mengetahui hubungan: (1) antara pengetahuan mahasiswa tentang ekosistem dengan sikap terhadap pelestarian lingkungan, (2) antara persepsi mahasiswa terhadap kesehatan lingkungan dengan sikap terhadap pelestarian lingkungan, (3) antara motivasi mengenai pemeliharaan lingkungan dengan sikap terhadap pelestarian lingkungan.
Penelitian dilakukan di Universitas PGRI Palangka Raya. Penelitian dilaksanakan selama bulan April sampai Juni 2014.

Metode penelitian adalah metode survai dengan analisis korelasional. Besar sampel ditetapkan 120 orang diambil secara multistage random sampling.

Pengumpulan data sikap terhadap pelestarian lingkungan, persepsi terhadap kesehatan lingkungan dan motivasi mengenai pemeliharaan lingkungan menggunakan instrumen berupa kuesioner dengan skala Likert. Pengumpulan data pengetahuan tentang ekosistem menggunakan instrumen tes.

Instrumen penelitian yang telah disusun berlandaskan konsep dan teori tersebut diujicobakan pada 40 responden. Hasilnya adalah koefisien reliabilitas (1) instrumen sikap terhadap pelestarian lingkungan 0,$91 ;$ (2) instrumen pengetahuan tentang ekosistem 0,87; instrumen persepsi terhadap kesehatan lingkungan 0,88; (4) instrumen motivasi mengenai pemeliharaan lingkungan 0,86 .

\section{HASIL PENELITIAN}

\section{Uji Persyaratan Analisis}

Hasil pengujian persyaratan normalitas galat taksiran dengan tehnik uji Liliefors disajikan dalam Tabel 1.

\section{Uji Homogenitas}

Hasil uji homogenitas varians data: $Y$ atas $X_{1}, Y$ atas $X_{2}$ dan $Y$ atas $X_{3}$ dengan uji Bartlett dirangkum pada Tabel 2. 
Tabel 1. Rangkuman Hasil Uji Normalitas

\begin{tabular}{|c|c|c|c|c|c|c|}
\hline \multirow{2}{*}{ No. } & \multirow{2}{*}{$\begin{array}{c}\text { Galat Taksiran } \mathrm{Y} \\
\text { atas }\end{array}$} & \multirow[b]{2}{*}{$\mathrm{n}$} & \multirow[b]{2}{*}{ Lo hitung } & \multicolumn{2}{|c|}{$\mathrm{L}_{\mathrm{O}}$ tabel } & \multirow{2}{*}{ Kesimpulan } \\
\hline & & & & $\alpha=0,05$ & $\alpha=0,01$ & \\
\hline 1 & $\mathrm{X}_{1}$ & 120 & 0,0442 & 0,0809 & 0,0942 & Normal \\
\hline 2 & $X_{2}$ & 120 & 0,0680 & 0,0809 & 0,0942 & Normal \\
\hline 3 & $X_{3}$ & 120 & 0,0579 & 0,0809 & 0,0942 & Normal \\
\hline
\end{tabular}

Keterangan :

$Y=$ Sikap terhadap Pelestarian Lingkungan

$X_{1}=$ Pengetahuan tentang Ekosistem

$\mathrm{X}_{2}=$ Persepsi terhadap Kesehatan Lingkungan

$X_{3}=$ Motivasi mengenai Pemeliharaan Lingkungan

$\mathrm{n}=$ Jumlah sampel

$L_{\text {hitung }}<L_{\text {tabel }}=$ Normal

Tabel 2. Rangkuman Hasil Uji Homogenitas Variansi

\begin{tabular}{ccccccc}
\hline \multirow{2}{*}{ No. } & $Y$ atas kelompok & $\mathrm{dk}$ & $\mathrm{X}^{2}$ hit & \multicolumn{2}{c}{$\mathrm{X}^{2}$ tabel } & Kesimpulan \\
\cline { 6 - 7 } 1 & $\mathrm{X}_{1}$ & 15 & 12,25 & 25,00 & $3=0,01$ & \\
2 & $\mathrm{X}_{2}$ & 28 & 25,22 & 41,34 & 48,28 & Homogen \\
3 & $\mathrm{X}_{3}$ & 41 & 40,80 & 56,94 & 64,95 & Homogen \\
\hline
\end{tabular}

Keterangan :

$Y=$ Sikap terhadap Pelestarian Lingkungan

$\mathrm{X}_{1}=$ Pengetahuan tentang Ekosistem

$\mathrm{X}_{2}=$ Persepsi Mengenai Kesehatan Lingkungan

$\mathrm{X}_{3}=$ Motivasi Pemeliharaan Lingkungan

$\mathrm{dk}=$ derajat kebebasan

$\mathrm{X}^{2}$ hitung $<\mathrm{X}^{2}$ tabel $=$ Homogen

\section{Pengujian Hipotesis}

Pertama, terdapat hubungan positif antara pengetahuan tentang ekosistem $\left(X_{1}\right)$ dan sikap terhadap pelestarian lingkungan $(Y)$ dengan persamaan regresi $Y=58,105+1,959 X_{1}$. Makna yang terkandung dalam persamaan regresi ini adalah setiap perubahan satu unit pada pengetahuan tentang ekosistem $\left(\mathrm{X}_{1}\right)$ akan diikuti perubahan 1,959 unit pada sikap terhadap pelestarian lingkungan $(\mathrm{Y})$ dengan arah yang sama pada konstanta 58,105 . Hasil uji signifikansi dan linearitas disajikan pada Tabel 3.
Kadar kekuatan hubungan antara $X_{1}$ dengan $Y$ bila $X_{2}$, dan $X_{3}$ dikontrol adalah $r_{y 1.23}=0,3425$ ditunjukkan pada Tabel 5. Hasil uji t sebesar $t_{\text {hitung }}$ $=3,73>t_{\text {tabel }}=2,36$ pada $\alpha=0,01$ menunjukkan bahwa korelasi parsial tersebut sangat signifikan. Meskipun terjadi penurunan hubungan sebesar 0,1215 namun tetap rnenggambarkan hubungan positif dan signifikan antara kedua variabel.

Kedua, terdapat hubungan positif antara persepsi mengenai kesehatan lingkungan dengan sikap mahasiswa terhadap pelestarian lingkungan dengan persamaan regresi $Y=53,385+0,560$ jika $X_{2}$ Makna yang terkandung dalam persamaan 
Tabel 3. ANAVA Regresi Linear Sederhana $Y=58,105+1,959 X_{1}$

\begin{tabular}{ccccccc}
\hline Sumber Variansi & $\mathrm{dk}$ & $\mathrm{JK}$ & $\mathrm{R} J K$ & $\mathrm{~F}_{\text {hitung }}$ & $\alpha=0,05$ & $\alpha=0,01$ \\
\cline { 6 - 7 } & 120 & $1,170,302$ & & & & \\
Total & 1 & $1,147,390$ & & & & \\
Koefisien (a) & 1 & $4,937,10$ & $4,937,10$ & $32,41^{* *}$ & 3,92 & 6,84 \\
Regresi (b/a) & 118 & $17,975,26$ & 152,33 & & & 2,26 \\
Sisa & 14 & $3,173,02$ & 226,64 & $1,592^{\text {ns }}$ & 1,79 & \\
\hline Tuna Cocok & 104 & $14,802,24$ & 142,33 & & & \\
Galat & & & & & & \\
\hline
\end{tabular}

Keterangan:

${ }^{* *}=$ Regresi sangat signifikan $\left(F_{\text {hitung }}=32,41>F_{\text {tabel }}=6,84\right)$

ns $=$ non-signifikan, regresi linear $\left(F_{\text {hitung }}=1,592<F_{\text {tabel }}=1,79\right)$

Tabel 4. Hubungan antara $X_{I}$ dengan $Y$

\begin{tabular}{cccccc}
\hline Korelasi & $\begin{array}{c}\text { Koefisien } \\
\text { Korelasi }(r)\end{array}$ & $\begin{array}{c}\text { Koefisien } \\
\text { Determinasi }\left(r^{2}\right)\end{array}$ & $t_{\text {hitung }}$ & & \multicolumn{2}{c}{$t_{\text {tabel }}$} \\
\hline$r_{y 1}$ & 0,464 & 0,215 & $5,693^{* *}$ & 1,98 & $\alpha=0,01$ \\
\hline
\end{tabular}

Keterangan:

${ }^{* *}=$ Koefisien korelasi sangat signifikan $\left(t_{\text {hitung }}=5,693>t_{\text {tabel }}=2,62\right)$

Tabel 5. Rangkuman Korelasi Parsial antara $X_{1}$ dengan $Y$

\begin{tabular}{ccccc}
\hline \multirow{2}{*}{ Korelasi } & \multirow{2}{*}{ Koefisien Korelasi $(r)$} & \multirow{2}{*}{$\mathrm{t}_{\text {hitung }}$} & \multicolumn{2}{c}{$\mathrm{t}_{\text {tabel }}$} \\
\cline { 4 - 5 } & 0,4381 & $5,29^{* *}$ & $\alpha=0,05$ & $\alpha=0,01$ \\
\hline$r_{\mathrm{y} 1.2}$ & 0,3371 & $3,89^{* *}$ & 1,98 & 2,62 \\
\hline$r_{\mathrm{y} 1.3}$ & 0,3245 & $3,73^{* *}$ & 1,98 & 2,62 \\
\hline$r_{\mathrm{y} 1.23}$ & &
\end{tabular}

Keterangan:

${ }^{* *} \quad=$ Koefisien korelasi sangat signifikan

$r_{y 1.2}=$ Koefisien korelasi $X_{1}$ dengan $Y$ jika $X_{2}$ dikontrol

$r_{y 1.3}=$ Koefisien korelasi $X_{1}$ dengan $Y$ jika $X_{3}$ dikontrol

$r_{y 1.23}=$ Koefisien korelasi $X_{1}$ dengan $Y$ jika $X_{2}$ dan $X_{3}$ dikontrol

regresi ini adalah setiap perubahan satu unit pada persepsi terhadap kesehatan lingkungan akan diikuti perubahan 0,560 unit pada sikap terhadap pelestarian lingkungan $(\mathrm{Y})$ dengan arah yang sama pada konstanta 53,385. Hasil uji signifikansi dan linearitas disajikan pada Tabel 6 .

Koefisien korelasi antara variabel persepsi terhadap kesehatan lingkungan dan variabel sikap mahasiswa terhadap pelestarian lingkungan $r_{y 1}=0,309$. Hasil uji $t$ menunjukkan bahwa nilai $t_{\text {hitung }}=3,53>t_{\text {tabel }}=2,62$ pada taraf signifikansi $\alpha$ $=0,01$ yang berarti bahwa koefisien korelasi tersebut sangat signifikan. Koefisien determinasi, yaitu hasil pengkuadratan koefisien korelasi antara $X_{1}$ dengan $Y$ adalah sebesar $r^{2}=0,095$ berarti bahwa sebesar $9,50 \%$ variansi sikap mahasiswa terhadap pelestarian lingkungan dapat ditentukan oleh persepsi terhadap kesehatan lingkungan. 
Kadar kekuatan hubungan antara $\mathrm{X}_{2}$ dengan $Y$ bila $X_{1}$, dan $X_{3}$ dikontrol adalah $r_{y 2.13}=0,2325$ ditunjukkan pada Tabel 8 berikut ini. Hasil uji t sebesar $t_{\text {hiung }}=2,60>t_{\text {tabel }}=2,62$ pada $\alpha=0,01$ menunjukkan bahwa korelasi parsial tersebut sangat signifikan. Meskipun terjadi penurunan hubungan sebesar 0,0765 namun tetap menggambarkan hubungan positif dan signifikan antara kedua variabel.

Ketiga, terdapat hubungan positif antara motivasi mengenai pemeliharaan lingkungan dengan sikap mahasiswa terhadap pelestarian

Tabel 6. ANOVA Regresi Linear Sederhana $Y=53,385+0,560 X_{2}$

\begin{tabular}{ccccccc}
\hline Sumber Variansi & $\mathrm{dk}$ & $\mathrm{JK}$ & $\mathrm{RJK}$ & $\mathrm{F}_{\text {hitung }}$ & $\alpha=0,05$ & $\alpha=0,01$ \\
\cline { 6 - 7 } & 120 & $1,170,302,00$ & & & & \\
Total & 1 & $1,147,389,63$ & & & & \\
Koefisien (a) & 1 & $2,183,07$ & $2,183,07$ & $12,43^{\star *}$ & 3,92 & 6,84 \\
Regresi (b/a) & 118 & $20,729,30$ & 175.67 & & & 1,94 \\
Sisa & 27 & $4,869,19$ & 180.34 & $1,03^{\text {ns }}$ & 1,61 & \\
\hline Tuna Cocok & 91 & $15,860,11$ & 174.29 & & & \\
Galat & & & & & &
\end{tabular}

\section{Keterangan:}

${ }^{* *} \quad=$ Regresi sangat signifikan $\left(F_{\text {hit }}=12,43>F_{\text {tabel }}=6,84\right)$

ns $=$ non-signifikan, Regresi linear $\left(F_{\text {hit }}=1,03<F_{\text {tabel }}=1,61\right)$

$\mathrm{dk}=$ derajad kebebasan

$\mathrm{JK}=$ Jumlah Kuadrat

RJK = Rata-rata Jumlah Kuadrat

Tabel 7. Hubungan antara $X_{2}$ dengan $Y$

\begin{tabular}{cccccc}
\hline \multirow{2}{*}{ Korelasi } & $\begin{array}{c}\text { Koefisien } \\
\text { Korelasi }(r)\end{array}$ & \multirow{2}{*}{$\begin{array}{c}\text { Koefisien } \\
\text { Determinasi }\left(r^{2}\right)\end{array}$} & $t_{\text {hitung }}$ & \multicolumn{2}{c}{$t_{\text {tabel }}$} \\
\cline { 5 - 6 } & 0,309 & 0,095 & $3,53^{* *}$ & 1,98 & $\alpha=0,01$ \\
\hline$r_{y}$ & & &
\end{tabular}

Keterangan:

${ }^{* *}=$ Koefisien korelasi sangat signifikan $\left(t_{\text {nitung }}=3,53>t_{\text {tabel }}=2,62\right)$

$\mathrm{r}_{\mathrm{y} 2}=$ Korelasi $\mathrm{X}_{2}$ dengan $\mathrm{Y}$

Tabel 8. Rangkuman Korelasi Parsial $\mathrm{X}_{2}$ dengan $\mathrm{Y}$

\begin{tabular}{ccccc}
\hline Korelasi & Koefisien & $\mathrm{t}_{\text {hitung }}$ & \multicolumn{2}{c}{$\mathrm{t}_{\text {tabel }}$} \\
\cline { 4 - 5 } & Korelasi $(r)$ & $2,94^{* *}$ & $\alpha=0,05$ & $\alpha=0,01$ \\
\hline$r_{\mathrm{y} 2.1}$ & 0,2610 & $2,81^{* *}$ & 1,98 & 2,62 \\
$r_{\mathrm{y} 2.3}$ & 0,2506 & 1,98 & 2,62 \\
$r_{\mathrm{y} 2.13}$ & 0,2325 & $2,60^{*}$ & 1,98 & 2,62 \\
\hline
\end{tabular}

Keterangan:

${ }^{* *} \quad=$ Koefisien korelasi sangat signifikan ( $t_{\text {hitung }}>t_{\text {tabel }}$ pada $\alpha=0,01$ )

* $\quad=$ Koefisien korelasi signifikan

$r_{\text {y2.1 }}=$ Koefisien korelasi $X_{2}$ dengan $Y$ jika $X_{1}$ dikontrol

$r_{y 2.3}=$ Koefisien korelasi $X_{2}$ dengan $Y$ jika $X_{3}$ dikontrol

$r y_{2.13}=$ Koefisien korelasi $X_{2}$ dengan $Y$ jika $X_{1}$ dan $X_{3}$ dikontrol 
lingkungan dengan persamaan regresi $Y=44,646$ $+0,552 X_{3}$. Makna yang terkandung dalam persamaan regresi ini adalah setiap perubahan satu unit pada motivasi mengenai pemeliharaan lingkungan akan diikuti perubahan sebesar 0,552 unit pada sikap terhadap pelestarian lingkungan
(Y) dengan arah yang sama pada konstanta 44,646. Hasil uji signifikansi dan linearitas disajikan pada Tabel 9.

Koefisien korelasi antara variabel motivasi mengenai pemeliharan lingkungan dan variabel sikap mahasiswa terhadap pelestarian lingkungan

Tabel 9. ANAVA Regresi Linear $Y=44,646+0,552 X_{3}$

\begin{tabular}{|c|c|c|c|c|c|c|}
\hline Sumber Variansi & \multirow{2}{*}{$\mathrm{dk}$} & $\mathrm{JK}$ & \multirow{2}{*}{$\mathrm{RJK}$} & $\mathrm{F}_{\text {hitung }}$ & \multicolumn{2}{|c|}{$\mathrm{F}_{\text {tabel }}$} \\
\cline { 6 - 7 } & 120 & $1,170,302,00$ & & & & \\
\hline Total & 1 & $1,147,389,63$ & & & & \\
Koefisien (a) & 1 & $4.309,64$ & $4,309,64$ & $27,34^{\star *}$ & 3,92 & 6,84 \\
Regresi (b/a) & 118 & $18.602,73$ & 157,65 & & & \\
Sisa & 40 & $6.261,83$ & 156,55 & $0,99^{\text {ns }}$ & 1,56 & 1,88 \\
\hline Tuna Cocok & 78 & $12.340,90$ & 158,22 & & & \\
Galat & & & & &
\end{tabular}

\section{Keterangan:}

** $\quad=$ Regresi sangat signifikan $\left(F_{\text {hit }}=27,34>F_{\text {tab }}=6,84\right)$

ns $=$ non-signifikan, regresi linear $\left(F_{\text {hit }}=0,99<F_{\text {tab }}=1,56\right)$

$\mathrm{dk}=$ derajad kebebasan

$\mathrm{JK}=$ Jumlah Kuadrat

RJK = Rata-rata Jumlah Kuadrat

Tabel 10. Hubungan antara $X_{3}$ dan $Y$

\begin{tabular}{|c|c|c|c|c|c|}
\hline \multirow{2}{*}{ Korelasi } & \multirow{2}{*}{$\begin{array}{l}\text { Koefisien } \\
\text { Korelasi (r) }\end{array}$} & \multirow{2}{*}{$\begin{array}{c}\text { Koefisien } \\
\text { Determinasi }\left(r^{2}\right)\end{array}$} & \multirow{2}{*}{$t_{\text {hitung }}$} & \multicolumn{2}{|c|}{$t_{\text {tabel }}$} \\
\hline & & & & $\alpha=0,05$ & $\alpha=0,01$ \\
\hline$r_{y 3}$ & 0,434 & 0,188 & $5,288^{* *}$ & 1,98 & 2,62 \\
\hline
\end{tabular}

Keterangan:

${ }^{* *}=$ Koefisien korelasi sangat signifikan ( $t_{\text {hitung }}=5,288>t_{\text {tabel }}=2,62$ )

$r_{y 3}=$ Korelasi $X_{3}$ dengan $Y$

Tabel 11. Rangkuman Korelasi Parsial antara $X_{3}$ dengan $Y$

\begin{tabular}{ccccc}
\hline Korelasi & Koefisien & \multirow{2}{*}{$\mathrm{t}_{\text {hitung }}$} & \multicolumn{2}{c}{$\mathrm{t}_{\text {tabel }}$} \\
\cline { 4 - 5 } & Korelasi $(r)$ & $3,26^{* *}$ & $\alpha=0,05$ & $\alpha=0,01$ \\
\hline$r_{\text {y3.1 }}$ & 0,2875 & $4,73^{* *}$ & 1,98 & 2,62 \\
$r_{\text {y3.2 }}$ & 0,3987 & $2,95^{*}$ & 1,98 & 2,62 \\
$r_{\text {y3.12 }}$ & 0,2624 & 1,98 & 2,62 \\
\hline
\end{tabular}

Keterangan:

${ }^{* *}=$ Koefisien korelasi sangat signifikan ( $t_{\text {hitung }}>t_{\text {tabel }}$ pada $\alpha=0,01$ )

$r \quad=$ Koefisien korelasi

$r_{y 3.1}=$ Koefisien korelasi $X_{3}$ dengan $Y$ jika $X_{1}$ dikontrol

$r_{y 3.2}=$ Koefisien korelasi $X_{3}$ dengan $Y$ jika $X_{2}$ dikontrol

$r_{y 3.12}=$ Koefisien korelasi $X_{3}$ dengan $Y$ jika $X_{1}$ dan $X_{2}$ dikontrol 
$r_{y 3}=0,434$. Hasil uji t menunjukkan $t_{\text {hitung }}=5,288$

$>t_{\text {tabel }}=2,62$ pada taraf signifikansi $\alpha=0,01$ yang berarti bahwa koefisien korelasi tersebut sangat signifikan. Koefisien determinasi, yaitu hasil pengkuadratan koefisien korelasi antara $X_{3}$ dengan $Y$ adalah sebesar $r^{2}=0,188$ berarti bahwa sebesar $18,80 \%$ variansi sikap mahasiswa terhadap pelestarian lingkungan dapat ditentukan oleh motivasi mengenai pemeliharaan lingkungan.

Kadar kekuatan hubungan antara $X_{3}$ dengan $Y$ bila $X_{1}$ dan $X_{2}$ dikontrol adalah $r_{y 3.12}=0,2624$ ditunjukkan pada Tabel 11 berikut ini. Hasil uji $t$ sebesar $t_{\text {hitung }}=2,95>t_{\text {tabel }}=2,62$ pada $\alpha=0,01$ menunjukkan bahwa korelasi parsial tersebut sangat signifikan. Meskipun terjadi penurunan hubungan sebesar 0,1716 namun tetap menggambarkan hubungan positif dan signifikan antara kedua variabel.
Keempat, terdapat hubungan positif antara Pengetahuan tentang Ekosistem, Persepsi terhadap Kesehatan Lingkungan dan Motivasi mengenai Pemeliharaan Lingkungan secara bersama-sama dengan Sikap Mahasiswa terhadap Pelestarian Lingkungan dengan persamaan regresi ganda $Y=10,621+1,338 X_{1}+$ $0,367 X_{2}+0,322 X_{3}$. Dari pengujian signifikansi diperoleh $F_{\text {hitung }}=18,132>F_{\text {tabel }}=3,91$. Artinya persamaan regresi sangat signifikan pada $\alpha=0,01$.

\section{Peringkat Hubungan}

Berdasarkan koefisien korelasi parsial peringkat hubungan setiap variabel bebas dengan variabel terikat ditunjukkan pada Tabel 14. Peringkat pertama hubungan paling kuat adalah antara pengetahuan tentang ekosistem $\left(X_{1}\right)$

Tabel 12. ANAVA Regresi Ganda $Y=10,621+1,338 X_{1}+0,367 X_{2}+0,322 X_{3}$

\begin{tabular}{ccccccc}
\hline Sumber Variansi & $\mathrm{dk}$ & $\mathrm{JK}$ & $\mathrm{RJK}$ & $\mathrm{F}_{\text {hitung }}$ & \multicolumn{2}{c}{$\mathrm{F}_{\text {tabel }}$} \\
\hline Regresi & 3 & 7314,27 & 2438,09 & $18,132^{\star *}$ & 2,63 & $\mathrm{\alpha}=0,01$ \\
Sisa & 116 & 15598,09 & 134,47 & & & \\
Total Dikoreksi & 119 & 22912,37 & & & & \\
\hline
\end{tabular}

Keterangan:

$* * \quad=$ Regresi sangat signifikan $\left(F_{\text {hitung }}=18,132>F_{\text {tabel }}=3,94\right)$

$\mathrm{dk}=$ derajad kebebasan

$\mathrm{JK}=$ Jumlah Kuadrat

RJK = Rata-rata Jumlah Kuadrat

Tabel 13. Analisis Korelasi Ganda $X_{1}, X_{2}$, dan $X_{3}$ dengan $Y$

\begin{tabular}{cccccc}
\hline Korelasi Ganda & $\begin{array}{c}\text { Koefisien Korelasi } \\
\text { Ganda }(\mathrm{R})\end{array}$ & $\begin{array}{c}\text { Koefisien } \\
\text { Determinasi }\left(\mathrm{R}_{2}\right)\end{array}$ & $\mathrm{F}_{\text {hitung }}$ & $\alpha=0,05$ & $\mathrm{~F}=0,01$ \\
\hline $\mathrm{R}_{\mathrm{y} .123}$ & 0,565 & 0,319 & $18,132^{\star *}$ & 2,63 & 3,94 \\
\hline
\end{tabular}

Keterangan:

$* \star \quad=$ Koefisien korelasi ganda sangat signifikan $\left(F_{\text {hitung }}=18,132>F_{\text {tabel }}=3,94\right)$

$R_{y .123}=$ Korelasi $X_{1}, X_{2}, X_{3}$ dengan $Y$ 
Tabel 14. Peringkat Hubungan antara Variabel Bebas dengan Variabel Terikat

\begin{tabular}{ccc}
\hline Variabel Bebas & Koefisien Korelasi Parsial & Peringkat \\
\hline $\mathrm{X}_{1}$ & $\mathrm{r}_{\mathrm{yl} .23}=0,3245$ & $\mathrm{I}$ \\
$\mathrm{X}_{2}$ & $\mathrm{r}_{\mathrm{y} 3.12}=0,2624$ & II \\
$\mathrm{X}_{3}$ & $\mathrm{r}_{\mathrm{y} 2.13}=0,2325$ & $\mathrm{III}$ \\
\hline
\end{tabular}

disusul peringkat kedua hubungan antara motivasi mengenai pemeliharaan lingkungan $\left(X_{3}\right)$ dan pada peringkat ketiga adalah hubungan antara persepsi terhadap kesehatan lingkungan $\left(\mathrm{X}_{2}\right)$ dengan sikap terhadap pelestarian lingkungan $(\mathrm{Y})$.

\section{KESIMPULAN DAN SARAN}

\section{Kesimpulan}

Berdasarkan hasil penelitian dapat ditarik beberapa kesimpulan sebagai berikut:

1. Sikap terhadap pelestarian lingkungan dapat ditingkatkan lebih baik melalui peningkatan pengetahuan tentang ekosistem. Pengetahuan tentang ekosistem menempati urutan pertama dalam konstribusinya pada sikap terhadap pelestarian lingkungan.

2. Sikap terhadap pelestarian lingkungan dapat ditingkatkan lebih baik melalui persepsi terhadap kesehatan lingkungan. Persepsi terhadap kesehatan lingkungan menempati urutan ketiga dalam konstribusinya pada sikap terhadap pelestarian lingkungan.

3. Sikap terhadap pelestarian lingkungan dapat ditingkatkan lebih baik melalui peningkatan motivasi mengenai pemeliharaan lingkungan. Motivasi mengenai pemeliharaan lingkungan berada pada urutan kedua dalam kontribusinya pada sikap terhadap pelestarian lingkungan.

\section{Saran}

Atas dasar kesimpulan penelitian di atas, diajukan beberapa saran sebagai berikut:

1. Dalam upaya meningkatkan pengetahuan tentang ekosistem di Universitas PGRI Palangka Raya, perlu peningkatan proses belajar mengajar, pengadaan buku-buku pelajaran mengenai lingkungan serta pelatihan bagi dosen yang mengajar di bidang pengetahuan lingkungan sehingga dapat diharapkan mahasiswa; (1) mempunyai sikap positif terhadap pelestarian lingkungan (2) didorong untuk menularkan sikap positif terhadap pelestarian lingkungan yang mereka miliki kepada orang tua dan sanak saudara masing-masing dan (3) melakukan penelitian selanjutnya terhadap variabel lain yang dapat meningkatkan sikap positif terhadap pelestarian lingkungan.

2. Dalam upaya meningkatkan persepsi tentang kesehatan lingkungan perlu dipertahankan bahkan jika mungkin ditingkatkan kebersihan di lingkungan kampus Universitas PGRI Palangka Raya dengan memasang sloganslogan yang mengajak kebersamaan dalam upaya peningkatan kesehatan, pemeliharaan dan pelestarian lingkungan serta pemasangan tong-tong sampah di setiap sudut kampus. Sejalan dengan itu perlu direncanakan untuk sewaktu-waktu atau 
secara berkala mahasiswa dilibatkan dalam kegiatan penghijauan, pemeliharaan dan perawatan lingkungan kampus yang dimulai dari ruang kuliah, kantor, dan halaman kampus.

\section{DAFTAR PUSTAKA}

Hardjasoemantri, Koesnadi. 2005. Hukum Tata Lingkungan. Gadjah Mada University Press. Yogyakarta.

Notoatmodjo S. 2003. Metodologi Penelitian Kesehatan. Rineka Cipta. Jakarta.

Slamet, Juli Soemirat. 1999. Kesehatan Lingkungan. Gadjah Mada University Press. Yogyakarta.

Soemarwoto, Otto. 2004. Ekologi, Lingkungan Hidup dan Pembangunan. Penerbit Djambatan. Jakarta.

Undang-Undang Republik Indonesia Nomor 23 Tahun 1997 tentang Pengelolaan Lingkungan Hidup.

Wawan, Dewi. 2010. Teori dan Pengukuran Pengetahuan, Sikap, dan Perilaku Manusia. Nuha Medika. Yogyakarta. 